\title{
Monosomy 7
}

National Cancer Institute

\section{Source}

National Cancer Institute. Monosomy 7. NCI Thesaurus. Code C36411.

A chromosomal abnormality consisting of the absence of one of the copies of chromosome 7 in somatic cells. 